\title{
The inviolateness of life and equal protection: a defense of the dead-donor rule
}

\section{Adam Omelianchuk ${ }^{*}$}

omelianchuk@gmail.com

\begin{abstract}
There are increasing calls to reject the dead-donor rule and permit organ donation euthanasia in organ transplantation. I argue that the fundamental problem with this proposal is that it would bestow more worth on the organs than on the donor who possesses them. What is at stake is the basis of human equality, which, I argue, should be based on an ineliminable dignity that each of us has in virtue of having a rational nature. To allow mortal harvesting would be to make our worth contingent upon variable quality-of-life judgments that can be based only on properties that come in degrees. Thus, rejecting the dead-donor rule comes at the expense of egalitarian principles with respect to the value each individual human life has in relation to the protections against killing.
\end{abstract}

Keywords Transplant ethics; Dead-donor rule; Killing; Moral status; Organ donation

\section{Introduction}

There are increasing calls to reject the dead-donor rule and permit organ donation euthanasia in organ transplantation [1-3]. In these proposals, a donor can authorize a surgical team to extract vital organs for transplant before death is declared with the understanding that the transplant surgery would bring about the donor's death — a practice George Khushf calls “mortal harvesting" [4, p. 331]. What can be said against such proposals? One might think that adopting them would have negative effects on donor trust and thereby lead to a net loss of organs donated for transplant. Others might think that they are incompatible with the physician's role as healer, which forbids the killing of patients for any reason $[5,6]$. As interesting as these arguments may

\footnotetext{
${ }^{*}$ Stanford University School of Medicine, Stanford, CA, USA
} 
be, I set them aside in order to develop what a "sanctity" or "inviolateness of human life" view might say against proposals for permitting organ donation euthanasia, since this view is largely neglected in the literature but was influential in guiding the ethics of early transplanters [7]. What this view should be called does not really matter to me. What does matter is that it be identified by its connection to political equality in the sense that Elizabeth Anscombe means when she writes, "In a just system of law, there will not be some class of people, identified by their origins or social status, who can murder or be murdered with impunity" [8, p. 254]. Unlike Anscombe, however, I will not pursue the meaning of "murder" (though I sympathize with her view). ${ }^{1}$ Rather, I will argue that the fundamental problem with mortal harvesting is that it bestows more worth to the organs than to the one who has them insofar as it requires that a class of people (the donors) be judged to have lives that are less worthy of protections against killing than those of another class (the recipients). What is at stake, then, is the very basis of human equality, which, as I will also argue, should be based on an ineliminable dignity that each of us has in virtue of having a rational nature inherent to our human life form. To permit mortal harvesting is to make life's worth contingent upon variable quality of life judgments that can be based only on properties that come in degrees. As I see it, the problem is that some people will be deemed less worthy of protections against killing based on differences in health status that will be more arbitrary or difficult to determine (or both) than the currently accepted death criteria.

In the first section, I frame the issue in terms of what makes killing wrong and defend the notion that the wrongness of killing involves an act of disrespect. I deny that it is our

\footnotetext{
${ }^{1}$ Her view is that the intentional killing of innocent human life is the "hard core" of murder; destruction of human life that is careless of, or indifferent toward, its worth also falls under the concept [9, p. 262].
} 
autonomous choice that is the primary object of respect; rather, I contend that it is the human person embodied as an individual substance with a rational nature — an instance of human life. In the second section, which is the heart of the paper, I explain that our rational nature is marked by the possession of a basic, natural capacity for rational action - a capacity to acquire the various social and creative capacities for actions that are ordered to, and constitutive of, human flourishing. This account conceives of human beings as members of a natural kind, and kindmembership is what matters for having this capacity, not the degree of its actual performance. I then address the appeal to marginal cases - anencephalic infants, patients in a persistent vegetative state (PVS), and so forth—which allegedly shows that killing such individuals is of no more concern than killing a nonhuman animal. In the third section, I address the objection that true respect involves honoring the autonomous choices of the donor and not the donor's life. In the final two sections, I show how political equality is threatened by a policy that would permit mortal harvesting. What follows, then, is my account of why mortal harvesting policies should not be adopted.

\section{The wrongness of killing: a matter of respect}

\section{Deprivation and respect}

Theories that seek to explain the wrongness of killing in terms of disrespect for some characteristic of the victim feature prominently in the ethics of killing. They are typically contrasted with harm or deprivation accounts, which make the badness of the victim's death central to the wrongness of killing. The deprivation account is represented well by Don Marquis (though see qualifications below), who says "for any killing where the victim did have a valuable 
future like ours, having that future by itself is sufficient to create the strong presumption that the killing is seriously wrong" [10, p. 195]. Thus, he contends, "Persons who are severely and incurably ill, who face a future of pain and despair, and who wish to die will not have suffered a loss if they are killed. It is, strictly speaking, the value of a human's future which makes killing wrong in this theory" [10, p. 191]. This claim seems intuitive and a vivid illustration of its power comes from Jonathan Glover:

It does not seem plausible to say that there is no conceivable amount of future misery that would justify killing someone against his will. If I had been a Jew in Nazi Germany, I would have considered very seriously killing myself and my family, if there was no other escape from the death camps. And, if someone in that position felt that his family did not understand what the future would feel like and so killed them against their wishes, I at least am not sure that this decision would be wrong. [11, p. 82]

Suppose this is right. How, then, would one explain the wrongness of, say, a Nazi SS officer's action when he shoots a distraught mother dead on her way to the gas chamber? After all, he eliminates the cause of her distress: the thought of watching her two small children die from poison gas twenty minutes later (suppose that because of this distress, she is incapable of enjoying the little time left with her children). One might think his action is wrong insofar as it causes bad effects for her kids and those around her or insofar as it comes from a vicious character (or both). Be that as it may, neither of these explanations addresses what the officer does to her. Since the deprivation account is concerned only with what he takes away from her, which certainly is not a "future of value" [10], on that account his shooting her does nothing bad to her and perhaps something good. This is hard to believe. What remains unexplained is the fact that he wrongs her-he does not merely act wrongly with respect to some principle of utility or theory of what makes someone virtuous.

Furthermore, there is a sense in which the Nazis wronged their victims equally. Suppose the 
woman's children die in the gas chamber with their elderly grandfather; the killing of the grandfather is just as objectionable as the killing of the grandchildren even though a greater deprivation of life goods is suffered by the children. While one's sense of tragedy may vary with the amount of life goods lost, the sense of injustice does not. Why is this? An intuitive, though I think not fully satisfying, answer is that the Nazis took their victims' lives without their consent. As Warren Quinn explains:

Among the several moral reasons you may have not to kill me, take me captive, or subject me to your idea of the good life, perhaps the most important lies in the simple fact that I choose, or would choose were I to consider the matter, that you do not. Viewed in this way these rights are nothing other than equally distributed moral powers to forbid and require behavior of others, and violations of them are nothing other than refusals to respect the exercise of these powers. [12, p. 49]

Since the choice to go on living is all or nothing, the violation of that choice is all or nothing.

Hence a principle of respect for autonomy remains unsatisfied when one takes the life of another, and this seems sufficient to explain how it is that the Nazis not only wronged their victims, but also wronged them equally.

\section{The disjunctive theory and its discontents}

Respect for autonomy, however, is not absolute; nearly everyone agrees that it would be impermissible to kill healthy people upon their request. ${ }^{2}$ Fortunately, respect theorists need not, and should not, deny that part of what explains the wrongness of killing is that it harms the

\footnotetext{
${ }^{2}$ A notable exception is John Harris, who writes, "Should I be permitted voluntarily to donate a vital organ like the heart? Again, if I know what I am doing then I do not see why I should not give my life to save that of another if that is what I want to do" [13, p. 113]. Yet his respect for autonomy is merely pragmatic, since he has (in)famously argued that it would be permissible to institute a "survival lottery" in which some people are killed at random for their organs regardless of their consent [14]. Those who insist that healthy people have an autonomy-based right to be mortally harvested will avoid the equality problems I raise in this argument (thanks to Brookes Brown for pressing this point).
} 
victim in terms of a deprivation of life goods lost in death. Nor are deprivation theorists required to deny the moral significance of respect (as Marquis does not). This compatibility explains the prominence of what I call disjunctive theories, which are deprivation theories that incorporate the moral significance of respect and identify autonomous choice as the relevant object of respect. Though such theories vary in their details, what unifies them is the general claim that the wrongness of killing can be explained either in terms of harm done to the victim or in terms of disrespect to the victim's autonomy, or both (e.g., $[12,15,16])$. On this view, it is permissible to kill an innocent person, $S$, if and only if (1) $S$ is not (or is acceptably) harmed by death and (2) $S$ gives valid consent to be killed by some humane means; it is wrong to kill $S$ if just one of these conditions is unsatisfied. That killing someone who meets these conditions might benefit others, as it would in organ donation, only bolsters the reason for killing by transplant surgery; hence the disjunctive theory is attractive to those who would permit mortal harvesting.

Plausible as it may be, the disjunctive theory is unsatisfying. What exactly counts as a harm and who decides whether or not it is acceptable? If harm is just a setback to one's interests [2, 17], and one has an interest in sacrificing one's life for others above all else, why must the donor even be sick? A healthy person, perhaps like the main character in the film Seven Pounds, ${ }^{3}$ could claim to be unacceptably harmed and disrespected if his preference to serve as a donor goes unsatisfied. Yet such an argument would merely reduce the case for mortal harvesting to the logic of preference satisfaction, making the disjunctive theory redundant. ${ }^{4}$ To be sure, the relevant sense of harm assumes something objectively valuable is lost in terms of a "worth-while

\footnotetext{
${ }^{3}$ In the film, the main character seeks redemption for involuntary manslaughter by planning to commit suicide in a way that would allow his lungs, liver, kidney, heart, and eyes to be donated.

${ }^{4}$ That healthy people are willing to give up their lives for the sake of organ donation is not a fanciful one. Stanford's heart transplant team was reportedly contacted by healthy individuals who wanted to sacrifice their lives for the sake of saving others and advancing medical knowledge [18].
} 
life" [11, p. 52], or "biographical life" [19, p. 179], or "a future of value" [10, p. 191], or an immediately exercisable ability "to act or do things" [20, p. 3]. If these sorts of things constitute what is lost in an act of harmful killing, then it seems there must be little, if anything, left to lose at the end of life for killing to be permissible. But who decides whether there is little, if anything, left to lose? If it is the patient, then the argument comes back to the logic of preference satisfaction, which makes the disjunctive theory redundant. If it is the doctor or some legal authority, then someone other than the patient is in a position to determine whether the harm of death would be acceptable or not in order for the patient's wishes to be honored. That is to say, the patient's wishes would be privileged only when someone with standing has judged the patient's life to not be worth living. Consequently, the patient's self-determination ends up being quite limited because she is empowered to choose mortal harvesting only under the condition that her life is (or will be) expendable for the sake of others when she is in a diminished state [21]; an autonomous choice for death deserves no respect if the patient is sufficiently healthy. Moreover, as David Vellemen argues [22], if the patient is terminally ill but chooses to go on living, her choice will require some sort of justification if she is to be judged rational. Since people are expected to provide reasons for their choices, the patient is compelled to justify her continued existence under the pain of irrationality in a way that healthy people are not. This inequality is contingent upon one's health status and therefore places an unfair burden on the sick so that they might enjoy one of the most basic rights in a just society: the right not be killed. The sort of "autonomy" given to the dying by whoever is authorized to grant it ironically masks an insidious form of paternalism about what lives are worthy of protection. Therefore, this version of the disjunctive theory should be rejected if autonomy is to have the sort of worthiness of respect it is assumed to have. 
On the other hand, it is also reasonable to think that the disjunctive theory would have autonomy respected too much. It may be against your will for me to poke you in the belly, but violating your autonomy in this way is not nearly as serious as killing you against your will, even if you have little time left. What your will is concerned with matters quite a lot more than the mere fact that you have a will concerned with something, which indicates that the respectworthiness of your autonomy is partly determined by goods that are more fundamental than the good of autonomy itself [23, pp. 58-59] (pace Quinn above [12, p. 49], asserting that such violations are "nothing other" than refusals to respect autonomy). Another way autonomy may be respected too much is found in arguments that conclude from considerations of suffering alone that incompetent individuals are just as entitled to the so-called "benefits of death" as competent individuals [24]. Since the suffering of the incompetent matters no less than that of the competent, it is unfair for the competent to be eligible to enjoy the purported "good" of death while the incompetent are not. Indeed, in this respect, the disjunctive theory has been recognized as a "dishonest" [19, p. 179], ad hoc proposal that compromises between autonomy-based and harm-based justifications for killing for the sake of garnering legal support for euthanasia. Daniel Callahan explains that requiring competence and suffering overdetermines the case for killingone or the other will do:

Each [requirement] has its own logic, and each could be used to justify euthanasia. But, in the nature of the case, that logic, it seems evident, offers little resistance to denying any competent person the right to be killed, sick or not; and little resistance to killing the incompetent, as long as there is good reason to believe they are suffering. There is no principled reason to reject such logic, and no reason to think it could long remain 
suppressed by the expedient of an arbitrary legal stipulation that both features, suffering and competence, be present. [25, pp. 108-109]

Even if the legal stipulations were to remain intact with respect to mortal harvesting practices, there would be no reason why the disjunctive theory should not be deployed to justify killing for the sake of medical experimentation. ${ }^{6}$ For those who are not willing to go that far, these problems at least motivate a search for a better account that answers the fundamental question: what is it that ought to be respected in a respect-based view of killing?

\section{The life of the human person as the primary object of respect}

I submit that the life of the individual human person ought to be the primary object of respect. By "human person," I mean a flesh-and-blood Aristotelian substance that is a rational animal, not something that just so happens to fall under an abstract description of being an autonomous agent, whatever that might be. Classically understood, the human person is an "individual substance of a rational nature" [27, p. 93], a definition that is hard to improve upon [28]. This enduring idea includes both autonomous and non-autonomous individuals, as recognized in the Belmont Report's statements on "Respect for Persons," according to which "persons with diminished autonomy are entitled to protection" and may be so severely compromised that they should be excluded from activities that may harm them [29, pp. 4-5]. Human persons, on this view, are simply instances of the human life form (more on this below), and they are entitled to a measure of respect no matter how diminished they might be.

\footnotetext{
${ }^{5}$ While competence may be "present" through an advanced directive, it still raises the question as to why such directives would be needed at all if the good of death can bring about an end to suffering and a set of healthy organs to others who need them.

${ }^{6}$ Indeed, voluntary research euthanasia has been recently advocated by Julian Savulescu [26].
} 
One must distinguish this view from the one that reduces respect for personhood to respect for autonomous agency, and consequently leaves those with diminished autonomy at risk of not being protected. As Therese Lysaught has shown [30], one can find this shift from the particular human being to the property of autonomy in the early editions of Tom Beauchamp and James Childress's Principles of Biomedical Ethics as well as in the US government's report on research involving human embryos $[31,32]$. In the first edition of their famous book, Beauchamp and Childress interpret Immanuel Kant as saying "a moral relation between persons is always one where there is mutual respect for autonomy," and then infer that "the principle of autonomy thus applies exclusively to persons capable of autonomous choice" [31, pp. 59, 60]. What might protect those with diminished autonomy is what they call "the principle of human worth," according to which "human life has an intrinsic value irrevocably destroyed" in an act of killing [31, p. 87]. While this principle of human worth resembles what I am defending, it is too abstract and impersonal, which perhaps explains why Beauchamp and Childress take its most reasonable interpretation to be that "killing is prima facie wrong and so permissible only if it is necessary to save the life of at least one other innocent person" [31, p. 88]—-something that is quite compatible with mortal harvesting! ${ }^{7}$ Contrast this watered-down principle with the statements of Paul Ramsey, who prohibits mortal harvesting "out of the respect due" to the human being that is "presented to us with its moral claims solely within the ambience of a bodily existence" [33, pp. 190, 191]. Further, contrast Ramsey's notion of respect as "holy awe" [34, p. 76] with the contemporary rhetoric of "respect" that has become so separated from the norms of protection and so abstracted from the bodily subject, that the public can be called to give "profound respect" to human embryos while at the same time being told it is quite permissible to destroy

\footnotetext{
7 The remaining part of the sentence is "or if it is necessary to preserve a morally worthy society" [31, p. 88].
} 
them for research purposes [35, p. 101]. Such "respect" is neither profound nor the kind anyone should want.

A recovery of respect for persons in their bodily life, where they are prioritized above whatever contingent properties they might have, is not only necessary for safeguarding the individual from abuse, but also sufficient to explain what is fundamentally wrong with killing: it simply destroys someone. ${ }^{8}$ Theories of the wrongness of killing that focus exclusively on the loss of some property of the person — whether it be a future of value or an autonomous will—are pathologically forgetful of the particular bearer of that property in their accounts of what makes killing wrong when it is wrong. ${ }^{9}$ As Sophie Grace Chappell remarks, "deprivation is not the main thing wrong in killing, even when it is part of what is wrong. In killing, the main point is not that something is taken away from someone, but that the someone is taken away" [37, p. 111]. The issue, then, is what grounds human dignity - that is, what make people worthy of respect such that they, as innocent persons, should always be protected from being destroyed for utilitarian benefit. $^{10}$

\footnotetext{
${ }^{8}$ Or for those pesky substance dualists, it simply destroys someone on this earth.

${ }^{9}$ When killing is wrong depends on whether the victim is innocent or not. One might wonder why non-innocence should make a difference to a view that bases moral status on the possession of a rational nature. If non-innocence makes a difference, then having dignity and being entitled to protections against killing are not coextensive. I accept the point. Here I follow Craig Paterson, who suggests that it is not the intrinsic status of a good (in this case, human life) that determines whether an instance of the good should be intentionally destroyed or not; rather, it is the nature of the demands imposed by the particular good in question [36, p. 83]. The life of an innocent human being, which ought to be respected in virtue of its dignity, demands that it not be intentionally destroyed. The life of a noninnocent human being cannot make that demand, since the activity of the non-innocent threatens the being and integrity of others who pose no threat. To protect non-innocent human life as much as innocent human life is to not protect innocent human life at all. Thus, the demands of human dignity are ordered to the protection of human beings who pose no threat to others, and the protections from killing one enjoys in virtue of having dignity disappear when one becomes a lethal threat. One should not think, however, that those who are non-innocent lose their dignity by virtue of their threatening behavior. Indeed, the respect non-innocent persons are due requires that the means undertaken to defend against their threat must be proportional to the threat they pose. Whatever one thinks of this argument is beside the point, however, since all donors are innocent in the sense that they are not a threat to anyone. ${ }^{10}$ Here I am thinking of Kant's distinction between "price" and "dignity" [38].
} 


\section{The species-norm account of the basis of human dignity}

I submit that the species norm of a rational nature, as defined by the human life form's ultimate capacity for rational action, is the basis of human dignity. The point of this account of human dignity is to indicate the priority of species membership, to show how a certain moral status is categorically endowed to members of the human species rather than individually achieved through some degree of rational performance. Thus I proceed with what might be called a groupbased account of moral status, in which membership in the natural kind "human" is sufficient (though not necessary) for having an ineliminable dignity that, at the very least, entitles one to protection against killing. ${ }^{11}$ The issues to be sorted out for my group-based account are (1) what is meant by the human life form, ultimate capacities, and rational action, (2) why these ideas matter morally, (3) how they account for ostensibly defective humans, and (4) how the charge of speciesism (and other objections) should be handled. These points will be addressed in turn in the remainder of the section.

The human life form's ultimate capacity for rational action

What does it mean to say that the human life form has a rational nature? By "human life form," I mean something general like the idea of a healthy, well-working human organism—something people demonstrate a working knowledge of whenever they identify an individual as being alive [41]. ${ }^{12}$ Embedded in this identification is an act of representation, a picture of health relative to the human form that is neither defined by some statistical model of averages nor falsified by a

\footnotetext{
${ }^{11}$ For a helpful overview of these ideas, see David Wasserman et al. [39]. For an account similar to mine that goes much deeper into the metaphysical issues, see Joseph Vukov's excellent paper [40].

${ }^{12}$ Here I follow the thought of Philippa Foot [42] and the magisterial work of Michael Thompson [43], drawing on a helpful summary of their work by Jennifer Frey [44].
} 
single counterexample; rather, it functions as a standard against which judgments are made about whether or not an individual instance of that life form is flourishing or working well. For example, the representational claim that "humans have 20/20 vision" means that the standard for human vision is $20 / 20$, regardless of the fact that the average measure for the human population falls well below 20/20. Likewise, the incomprehensible behavior of a toddler is no counterexample to the claim that "human beings give reasons for their actions." Linguistically, such claims have the form The $S$ is/has/does $F$, An $S$ is/has/does $F$, or $S$ 's are/have/do $F$ and are used as "essence-expressing generics" [45, p. 231]. Michael Thompson draws attention to how the truth of these judgments, what he calls "natural historical judgments" [41, p. 49], depends not on some hypothetical ideal, which involves referencing some other possible world where everything goes right for an individual, but on a substantive knowledge of a paradigmatic instance of the life form in question. Natural historical judgments have their own logic which presupposes that, at some time, the judgment's subject existed so that it might serve as an exemplar of its kind - which is to say, it fulfilled the purposes that members of its kind are internally directed to fulfill and lived the way in which members of its kind are supposed to live as the kind of thing that they are. It is tempting to think of the human life form as a kind of Platonic ideal or abstraction that each of us more or less exemplifies, but that is a mistake. Rather, the life form of a living thing is embedded in the body that bears it, which I submit is characterized by its ultimate capacities, the fulfillment of which constitutes the idea of a wellworking member of that species.

By “ultimate capacity," I mean an active and internally directed dispositional power that operates at the highest level or organization. The natural historical judgment that "the human uses language in order to communicate" is made true by the human's ultimate capacity for 
language use, which grounds the lower-order capacities to speak Mandarin, Spanish, or English

(or all three). That some humans cannot use any language due to early-stage development or pathological conditions does not negate the fact that they, or members of their kind, have this ultimate, higher-order capacity for language use; rather, the realization of this capacity is blocked or pending the contingent acquisition of the lower-order capacities to use a specific language. A being's ultimate capacities in the sense described define its intrinsic potentiality, a potentiality that is actively oriented toward bringing about its own fulfillment despite whatever obstacles it faces until death brings its activity to an end. The language faculty is not a passive capacity in the sense that a being may be made capable of using language through modification by some external work of genetic engineering or technological interference. While such an engineered capacity may reveal something about how a creature can be acted upon, it reveals nothing about how the creature is supposed to act. Ultimate capacities, by contrast, do convey how a being is supposed to act and therefore serve both to ground criteria that distinguish one kind from another and to mark the line between health and enhancement for members of a given kind. A life form's ultimate capacities, then, define what kind of life form it is, what it strives for, and what it means for it to flourish.

Lastly, I take "rational action" to be an umbrella term for actions that are guided by intentions to bring about some good or benefit, where these intentions are communicable to others. To be sure, there is a sense in which some nonhuman animals like dolphins and chimps engage in rational action insofar as they engage in means-to-ends reasoning and pre-linguistic communication [46]. ${ }^{13}$ Yet what remains distinctive of human animals is that it is within their

\footnotetext{
${ }^{13}$ The implication, of course, is that chimps and dolphins should be accorded a measure of respect that would protect them from being hunted or experimented on as they often are. One might think they are on the borderline, but that is no reason not to err on the side of giving them a high degree of protection.
} 
nature to acquire further capacities not only to pursue the goods constitutive of their flourishing, but also to give and evaluate reasons for pursuing them. ${ }^{14}$ To be sure, there will be disagreement about just what these goods are, but the goods of life and health are two of the most uncontroversial, since they are foundational to the pursuit of all other goods and worth pursuing for their own sake. Those who advance other criteria — such as the capacity for selfconsciousness, the capacity to form special relationships, or the capacity to feel pain — are hardpressed to deny that all of these things are shaped by our rational nature, which makes them qualitatively different from their occurrence in nonhuman animals. Hence the rationality criterion has enjoyed enduring relevance in spite of perennial criticism.

\section{The moral significance of ultimate capacities}

Whatever they may be, the criteria for serious moral status (dignity, in my view) have to be framed in terms of capacities. The occurrence of a morally relevant activity is just the telos of an immediately exercisable capacity to bring it about, which is just a first-order capacity to perform the relevant action that is not impeded by some circumstance or condition [48, p. 26]. Of course, the capacities to bring about relevant action can be blocked rather easily — a little anesthesia will do the trick. But obviously people maintain their moral status while under anesthesia. The same is true of those who are in a coma. Terry Wallis, a man who awoke from a nineteen-year-long coma and recovered fluent speech [49], ${ }^{15}$ maintained human dignity throughout his ordeal — he did not suddenly regain it when he woke up. ${ }^{16}$ I submit that what accounts for this continuity is

\footnotetext{
${ }^{14}$ Here I am indebted to the work of Justin Matchulat [47] for helping me clarify these issues.

15 "Coma" should be taken in a loose sense as Wallis was actually in a minimally conscious state.

${ }^{16}$ I pause here to address the distinction between having dignity and feeling dignified. The former stays with us so long as we are alive, while the latter comes and goes depending on whether we perceive that we are meeting, or being treated in accordance with, criteria for our conception of self-respect.
} 
that he retained a second-order capacity to possess the first-order capacities. When capacities are arranged in a hierarchal fashion in order to make sense of temporary change scenarios like these, they must culminate in ultimate — or root or radical or basic or natural — capacities that continue to endure through time [50, pp. 200-203]. It is by virtue of bearing a human life form that Terry's body presented observers with the fact that he persisted as the sort of creature who is supposed to function in the ways relevant for being a subject of rights; that is to say, he continued to have a nature characterized by a second-order or ultimate capacity to acquire the relevant capacities for moral agency, even though the former was blocked for a very long time. His possession of a human life form, then, is sufficient to have generated duties in others to care for, and not kill, him. Unless one wants to deny that Terry maintained his status as a rights-bearer throughout the course of his condition, higher-order capacities must be taken into account. Yet if they must be taken into account, they must matter morally.

\section{The moral status of "defective" humans and permanent changes}

Everyone knows that some changes are permanent; some injuries are so devastating that there is no coming back from them. Since the foregoing argument is limited to temporary changes, in which there is a (realistic?) possibility of recovery, it seems inapplicable to those who are permanently changed or for whom the possibility of recovery is vanishingly remote. Thus, as interesting as the argument may be for establishing the moral status of the very young or temporarily unresponsive, it does nothing for those who are typically considered eligible for mortal harvesting: anencephalic children and PVS patients [51, p. 15]. How such cases should be accounted for depends on whether we can survive the loss of our ultimate capacity for rational action. The question to be settled, then, is whether the ultimate capacity for rational action is essential to members of the human species. What reason is there to think anyone who has the 
capacity to live a biologically human life — one that begins at conception/twinning or implantation and ends in death — automatically has a capacity for rational action?

The answer derives from the natural goodness account of species norms articulated above: one cannot make sense of the human life form without conceiving of it as having a rational nature. While this claim is startling, it is more plausible than one might initially think. Indeed, evidence for it can be found even in the writings of the fiercest critics of the claim that human beings have a basic capacity for rational action. Consider the words of Jeff McMahan when he speaks of "a defective human embryo that lacks the potential to develop into anything other than an anencephalic infant" [15, p. 210] (emphasis added). Or consider those of Peter Singer, who takes the following to be "obviously true":

If we compare a severely defective human infant with a nonhuman animal, a dog or a pig, for example, we will often find the nonhuman to have superior capacities, both actual and potential, for rationality, self-consciousness, communication, and anything else that can plausibly be considered morally significant. [52, p. 201] (emphasis added)

McMahan concurs when he says that those who are "severely retarded" are not only cognitively comparable to certain nonhuman animals, but "they also have no more potential than those animals" $\left[15\right.$, p. 205] (emphasis added). ${ }^{17}$ Now, there is a sense in which these claims are obviously true if the authors are talking only about some level of intrinsic potential, but it seems

\footnotetext{
${ }^{17}$ Throughout his treatment of potential, McMahan is concerned with the distinction between intrinsic and extrinsic potential, or in other words, an active and internally directed potential to develop according to an information-rich design plan and the potential to be able to receive an intervention from the environment or technology to bring about different stages of development. As interesting as his remarks are, I believe they are beset by a pervasive and, in my view, unprincipled use of pathological labels (e.g., retarded, deficits, disability, etc.) that are inattentive to the significance of the logic of statements about natural defect, which ultimately presuppose the idea of the human life form I advanced earlier.
} 
they are making a stronger claim about any level of intrinsic potential. ${ }^{18}$ What is puzzling about

these claims is that if such individuals lack an active, self-directing potential for rational action at every level, then they are not "defective" or "retarded" in any way. They simply develop as they are supposed to develop and actualize exactly what they are in potency. Yet McMahan and Singer classify these individuals in the set of things which have gone awry by use of pathological labels. ${ }^{19}$ Taken at face value, claims about "defective" humans are claims about how they are not supposed to be; rather, they presuppose the idea that humans are supposed to develop into, and function as, mature members of their species. The old-fashioned idea of a human nature perfected by its complete development and the species-grounded norms associated with concepts like proper function haunt these claims, despite their broadly neo-Humean background assumptions. $^{20}$

There is good reason to believe that an ultimate capacity for rational action is present even in cases of severe disability or injury, because one would not be able to make sense of disability or

\footnotetext{
${ }^{18}$ This also appears to be the case with Franklin Miller and Robert Truog, who, when writing of those who fall just short of whole-brain death, say, "these patients lack any capacity for experience, owing to profound brain damage and the absence of any responsiveness to stimuli indicative of sensory awareness" [2, p. 121] (emphasis added).

${ }^{19}$ This tension is especially evident in McMahan's writings where he seems to assume a genocentric view of organisms, which views organisms and their features as being determined by their genetic code. This explains his difficulty in making sense of a human being without a genetic basis for the development of a rational nature that is still "internally directed toward the full realization of its inherent nature as a rational being" [53, p. 90]. Indeed, he ought to be puzzled if one's genetic constitution exhausts one's internally directed capacities. But why assume that? An organocentric view of organisms takes more into account, specifically dynamic epigenetic systems, to explain how it is that an organism's development is internally directed. (The genocentric/organocentric distinction belongs to Brian Goodwin [54, p. 3].) On this view, a condition like anencephaly would arise not from some genetic mutation, but from disruptions in the interaction of epigenetic factors. This controversy over the nature of the organism is not obscure either as it turns up in cancer research [55,56]: is cancer caused by genetic mutations or developmental problems? My point, however, is not to say what happens in anencephaly; rather, it is to say that if it is a result of some genetic mutation and genocentrism is true, then one should not, as McMahan does, speak of human organisms with anencephaly as undergoing some developmental failure.

${ }^{20}$ Note McMahan's candid admission to Tim Mulgan [57], when he says Mulgan is "obviously right" in saying "McMahan wants to combine a naturalistic, broadly Humean, picture of a world where continuous properties come in degrees, with a set of Kantian intuitions that clearly require sharp boundaries between persons and non-persons. This is an essentially unstable combination" [53, p. 94; 57, p. 458]. It should also be noted that there is a tension in McMahan's writings about how comparative judgments derived from species norms inform the notion of deprivation despite his commitment to moral individualism (see Christopher Grau [58] for an astute reading).
} 
injury if such a capacity were not essential to human beings in their nascent or waning forms.

While the language of "natural defect" has been spelled out most clearly by Thompson and Foot, the idea is not a new one. It is found in Aristotle when he says:

If, though either the thing itself or its genus would naturally have an attribute, it has it not; e.g. a blind man and a mole are in different senses "deprived" of sight; the latter in contrast with its genus, the former in contrast with his own normal nature. (Met. 5.22.1022b24-7, in [59, p. 772])

Human injuries and disabilities, then, are understood in light of the normal nature of human beings, understood in terms of the species norms entailed by the human life form. As Thompson writes, "every thought of an individual organism as alive is mediated by thought of the life-form it bears. A true judgment of natural defect thus supplies an 'immanent critique' of its subject" [43, p. 81]. More clearly, he says:

Your observations, which are at bottom always observations of individual organisms, will thus lead in the end to a possible critique or evaluation of individual organisms and their parts and operations. And they will lead to the articulation of general standards of critique applying to organisms of the kind in question. This sort of critique of the individual is everywhere mediated by the attribution to it of a specific form; to bring an individual under a life form is, we might say, at the same time to bring it under a certain sort of standard. [41, p. 55]

These evaluations need not be invidious or stigmatizing; rather, they should be taken as revealing that the creature in question is unable to get what it needs in order to fully flourish (the best ways to meet those needs are up for debate). As Jennifer Frey remarks, "This lack or absence of something that ought or needs to be present for the individual to flourish is the basis of the judgement of natural defect" [44, p. 95]. No doubt, all things considered, a blind person can be healthier than a sighted person, but if all other things are equal, a sighted person is healthier than a blind one. Yet this ceteris paribus comparison does not hold between humans and moles; nor 
would it hold, for the same reasons, between functioning individuals and the sort of individuals Singer and McMahan call "defective" if they are correct that such individuals have no intrinsic potential for rational action at any level.

One thinker who is refreshingly consistent on this point is Martha Nussbaum. She writes:

Some types of mental deprivation are so acute that it seems sensible to say that the life there is simply not a human life at all, but a different form of life. Only sentiment leads us to call the person in a persistent vegetative condition, or an anencephalic child, human. [60, p. 187]

She believes this because in cases of PVS or anencephaly, "all possibility of conscious awareness and communication with others is absent," and therefore such individuals are incapable of flourishing despite their caretakers' bests efforts [60, p. 187]. Yet there has to be more than just sentiment involved. ${ }^{21}$ Complex matters of personal identity and human ontology are at play in the ethics of killing, but there is good reason to believe that whatever the human person is, it has the ultimate capacity to live a biologically human life [61]. It is one thing for a PVS patient's friends and relatives to think that their loved one now lives a life not worth living or no longer exists as a person in some performative sense; it is quite another to think that their loved one is not there at all [62, p. 95]. Of course, one could embrace a tough-minded body-self dualism, which identifies us with something that can only be accidentally related to the human organism, but body-self dualism is both contrary to Nussbaum's assumptions and metaphysically dubious [63]. It fails to recognize the rational nature of the human life form as embodied and instead treats the living body merely as an independent object which contingently

\footnotetext{
${ }^{21}$ The problem with sentiment is that it cuts both ways: it may very well be that what motivates some to literally dehumanize the PVS patient and the anencephalic baby is sentiment, the kind that expresses contempt rather than care for the body before them.
} 
hides a rational self [47, p. 417]. Nor should it be assumed that the PVS patient or anencephalic child lacks any capacity to have a flourishing life at any level. It is reasonable to suppose that someone in a PVS who is protected and cared for has a more flourishing life than one who is starved, mocked, or sexually abused. The same can be said for the anencephalic child; it is better for the baby to be held and made comfortable in the little time that remains than to be thrown in a medical waste bin as though she were on the same metaphysical plane as her placenta—of human origin, but not a human being. ${ }^{22}$ It is simply not the case that nothing good or bad can happen to a person if that person has no way of experiencing what is happening. The capacity to experience one's state of flourishing may be absent, but that capacity is not required to have the opportunity to flourish as such. ${ }^{23}$ Such opportunities may be limited and will look quite different from those of a healthy adult, but they are nevertheless real opportunities with real human goods at stake. ${ }^{24}$

Another problem: either the PVS patient and anencephalic child are human or they are not. If they are not, then they cannot be called "injured" or "defective" for they cannot be appropriately measured against the human life form at all. They represent an absence of mental capacity, not a deprivation of it, because the subject of deprivation - the human being - no longer exists. There is also no classification for these bodies: what exactly is the life form that they bear if it is not a human life form? No answer is given. Similarly, at least for the PVS patient, note the oddness of there being a human organism as a whole the moment before the relevant capacities are lost, at which point it suddenly goes out of existence, only to be instantly replaced by a similar looking

\footnotetext{
${ }^{22}$ For an especially moving account of how an anencephalic baby was loved and cared for before dying and having his body donated to research, see Sarah Gray’s beautiful memoir [64].

${ }^{23}$ The same is true of being harmed; one need not be aware of the harm in question to be harmed.

${ }^{24}$ I owe these points to Christopher Tollefsen [65, pp. 217-218].
} 
organism as a whole which is free of any known species category. To be sure, an argument from oddness is not sufficient to undermine this view, which literally dehumanizes these living bodies as a consistent metaphysical thesis, and no amount of empirical evidence is going to determine whether or not this thesis is true. Yet Ockham's razor should lead to a simpler explanation: once the relevant capacities are lost, what is left is a human being that is profoundly disabled inasmuch as it lacks what is necessary to activate its ultimate capacity for rational action [66, p. 15].

What changes, then, in permanent scenarios is not the nature of the human being. The distinctive feature of the permanent cases at issue is that medical science does not know how to cure or reverse such conditions as anencephaly or PVS. Indeed, permanence is compatible with the idea that one's condition can, but will not, be reversed, given a present and foreseeable lack of the requisite technical resources for reversing it. The temporary change argument is concerned with the metaphysical conditions that assume (for conditional proof) that enough time and technical know-how are operative to make the restorative changes, not the actual conditions in which patients might find themselves.

\section{Species membership and its ethical significance}

Obviously, the criterion for species membership I am working with is essentially metaphysical, not merely biological. In the general experience, human beings are the only rational animals around, so it is natural to prioritize their lives over those of nonhuman animals. If we ever encounter intelligent Martians, hyper-evolved chimpanzees, or the talking beasts of Narnia, they too should be classified as rational animals. One could even be so generous as to call them "human" as the Thomists would, but if one hesitates to go that far, then so be it: all that matters 
is that these beings are classified as rational animals, for that is sufficient to determine their moral status. Thus, the problem of speciesism is avoided, since what is problematic is the assumption that only biological concepts of species are relevant for determining moral status. Here the biological concept is not privileged; what matters is the metaphysical concept.

Is the metaphysical concept too broad? One might think it invites the "Anything you can do, an animal can do too" objection. McMahan's articulation of it is representative:

If it is physically possible, through some as-yet-undiscovered form of genetic therapy, to augment a defective fetus's brain in a way that will enhance its future cognitive capacities, it is surely physically possible to achieve the same result in an animal—for example, a dog. If, therefore, we claim that a fetus with cerebral deficits is a potential person on the ground that it is physically possible for its brain to develop in ways that would be identity-preserving and would overcome or repair the deficits, we must concede that a dog is a potential person for the same reason. [15, p. 312]

A dilemma emerges: either embrace the dignity status of the whole animal kingdom or accept the charge of speciesism. Yet this objection assumes an ambiguous concept of potentiality. While it may be the case that it is physically possible for an animal, $a$, to perform a function, $F$, provided that $a$ has the potential for $F$, it is not necessarily the case that $a$ has the potential for $F$ if it is physically possible for $a$ to $F$. Consider again Aristotle's example; suppose that it is physically possible for subterranean blind mole rats (Spalax) to see by way of some as-yet-undiscovered technology. It does not follow that the subterranean blind mole rat has the kind of potential to see that I am talking about - an active potential intrinsic to its kind that is internally directed by its own nature to see. In the imagined case, the mole rat is made to see in spite of its nature, which is not internally directed toward the development of sight. My argument stipulates simply that an active capacity for rational action is sufficient for moral status, not that there may be some passive capacity in place to receive an active capacity for rational action. 
Nevertheless, some think that what is ethically significant is not the possession of a basic active capacity for rational action in itself, but the degree of remoteness or nearness of its actualization. John Lizza offers the following thought experiment to illustrate why:

Suppose that we have the knowledge and technology to clone the skin cell but lack the knowledge and technology to correct the genetic defect in the anencephalic embryo. Suppose further that we had some dire need to increase the human population and that the cloning technology was in very limited supply. Even though the anencephalic embryo might be said ... to have the active potential for intellect and will with assistance, we would not value it as much as the skin cell and cloning technology that could "produce" a human being. If one had to perform triage and devote resources to either the anencephalic embryo or the skin cell, it would be ethically justified to devote those resources to the skin cell rather than to the embryo. [67, p. 26]

The implication is that the value of one's potentiality for rational action, whether it be active or passive, depends on the likelihood of its being realized. To be sure, the time it might take for someone to recover is going to factor into what sort of treatment options, if any, might be chosen. Yet I am concerned not with decisions to treat or the allocation of resources, but rather with decisions to destroy, and the decision not to treat is not necessarily a decision to destroy. Nor should it be assumed that potentiality has only instrumental worth and should not be taken as evidence of intrinsic worth. If I am now under anesthesia and will not wake up for another hour, and it is true that I will be killed by a falling meteor five minutes from now, I still retain my dignity status. The contingent certainty of my not waking up is simply irrelevant as to whether I retain my worth as a human being, which generates duties in others not to kill me prior to the meteor strike. Another way of stating the problem is that Lizza assumes that the ethical significance of human potentiality is exhausted by what its actualization becomes, namely a person, and therefore its importance depends on when and if its actualization will occur. But an active capacity for rational action that is intrinsic to a thing is constitutive of a thing's beingwhich is to say, it indicates what the thing is and helps explain why it has non-instrumental worth 
regardless of its circumstances.

\section{Is a respect-for-donor rule different from a dead-donor rule?}

It is worth considering a final objection to my thesis that killing people for their organs

disrespects the worth of human life: that I misunderstand the true nature of respect. As Elysa

Koppelman claims:

By applying the [dead-donor] rule, we are failing to help patients achieve the fate that best fulfills their personhood. And this failure, especially given the implications of medical progress, reflects a moral cowardice and an abdication of our common humanity. By changing our focus we will realize that life and death distinctions are not always compatible with respect for persons. [68, p. 7]

She reaches this conclusion through an argument which can be formalized like so:

1. If one has indicated that one wants to be an organ donor, and forgo life-sustaining treatment when brain dead or in a PVS, then one is harmed by being denied the opportunity to donate in these circumstances.

2. This harm is a form of disrespect.

3. Therefore, any person who is denied the opportunity to donate in these circumstances is disrespected.

Because the dead-donor rule is the source of disrespect, Koppelman calls for its replacement with a "respect for donor" rule [67, p. 7], which considers patients' life history, decisions, and values, not whether they are dead or alive. This, in her view, is a more holistic concept of human personhood. What matters are one's ends as set by the person and one's life history as shaped by the person, including with the directives for what others are to do after death or incapacitation. These things, she thinks, are the substance of our shared humanity; the mere possession of a rational nature embodied in a human life form is not decisive. Therefore, if one's life history 
includes directives to be volunteered for transplant surgery under the condition that one is alive but irreversibly unconscious, then the ethics of respect generate a duty in others to honor them.

A close inspection of Koppelman's argument, however, reveals an ambiguity in her use of the phrase "opportunity to donate" $[68$, p. 7]. Even those who deny that brain death is death can agree with her conclusion if the opportunity to donate means the opportunity to work with a transplant team to remove vital organs after a determination of death by circulatory criteria. That someone should not be denied this opportunity is, of course, compatible with the dead-donor rule, which is contrary to her assumptions. To make the conclusion incompatible with the deaddonor rule, the opportunity to donate must mean the opportunity to be killed on the operating table by one's transplant surgeons. But is it really the case that one is disrespected if one is denied this opportunity?

Suppose this true - that to deny an advance directive to die by transplantation is to disrespect the one who issues it. It then follows that under such circumstances someone from the transplant community would be obligated to kill the donor. This obligation follows because norms of respect generate rights claims on behalf of the one who is owed respect, and rights entail obligations. Yet the fact is that no one is obligated to kill her. The problem for Koppelman's respect-for-donor rule is that it ends up demanding a disproportionate amount of respect to the donor's autonomy; it effectively nullifies the autonomy of transplant surgeons not to engage in mortal harvesting. Perhaps this outcome is not objectionable to those who are eager to deny conscience rights to physicians, but I suspect that it is objectionable to many transplant surgeons themselves. If so, then what is needed is an argument that reaches a weaker conclusion: that transplant surgeons are permitted to kill donors under such circumstances, not that they are obligated to do so. 
Reaching this weaker conclusion is no problem if Koppelman assumes (and she does) that the life of PVS patients is of such a low worth that within the framework of informed consent, they no longer deserve protection from being killed. If she wants to exclude healthy people from the donor pool (and she does), then she must answer the question as to what gives human life its worth, such that one should not be killed even upon request. Koppelman's answer is the wellworn psychological property of being capable of forming desires and interests [68, p. 8; 69]. Contrasting the PVS patient (whom she permits to be killed through informed consent) to the severe Alzheimer's patient (whom she does not), she writes of the former, "There isn't really anything that being in such a state is like, for being in such a state is like being in no state at all" $[68$, p. 8]. Yet the same is true of being under anesthesia or in a deep sleep: there is no felt experience of those states either. Clearly, what matters is some level of capacity to get out of those states, but then it becomes necessary to ask: what level of capacity for getting out of an unconscious state is morally relevant? I submit that for any given non-ultimate level of capacity, someone could run a temporary change argument, in which a patient redevelops the capacities relevant for moral status, and then conclude that the patient had moral status all along. Without an argument for why it should be believed that PVS patients have no ultimate active capacity for rational action, there is no way to safely claim that they lack moral status, which, again, is contrary to Koppelman's assumptions.

Furthermore, Koppelman's preferred way of limiting the freedom of healthy people to sacrifice themselves through mortal harvesting only serves to bolster my contention that basic, natural capacities are what is morally relevant. As someone who is sympathetic to Kant's moral framework, Koppelman believes "it can be argued that the end of giving vital organs when not in a suspended state [i.e., brain death or PVS] is almost always irrational or immoral, while the end 
of giving vital organs when in such a state is not" [68, p. 8]. Here she finds compelling Kant's argument that a suicidal will should not be respected in that it seeks to annihilate the very thing that merits respect: a will that is capable of setting ends for itself. ${ }^{25}$ Kant's point is that an autonomy-based right to withdraw oneself from all the duties of respect one is owed involves a contradiction: we cannot divest ourselves of our worth by virtue of exercising the capacity that gives us our worth [71, p. 84]. So if PVS patients no longer have this capacity, then their wishes to die by transplant surgery as indicated in advance generate no paradox of autonomy in which one wills both to be respected and to be annihilated. Yet if this line of reasoning is granted, the question is begged with respect to whether PVS patients actually have the capacity for rational action at any level. I say they do for, if they did not, then they could not intelligibly be understood as injured. Therefore, it should not be assumed that donors can consent-even in advanced directives - to be treated in a way that makes their lives comparably less valuable than their organs, as though their disabled bodies were mere receptacles of coveted pieces of tissue that can be mined for beneficial purposes. This privileging of the health of the organs over the life of the human being is what is fundamentally wrong with mortal harvesting.

\section{The basis of human equality}

Let me take stock. Essentially, my argument is that anything that has a basic or ultimate capacity for rational action has dignity status; all human beings by virtue of their life form have this capacity, no matter their maturity level or disability status; therefore, all human beings have dignity status, which entitles them to protections against killing. This argument was made with a

\footnotetext{
${ }^{25}$ See Michael Cholbi for an excellent overview of this argument [70].
} 
view toward providing a basis for human equality. Any basis that depends on properties that come in degrees is flimsy at best. The chief virtue of McMahan's work is the realization that liberal egalitarian principles must be rejected if moral status is made to depend on the instantiation of certain psychological properties. He recognizes this explicitly [53, p. 104], yet he is willing to follow his time-relative interests view where it leads. In particular, he is willing to claim that, ceteris paribus, killing a healthy orphaned newborn infant for its organs is permissible, since he thinks a newborn's "psychological connectedness" is not strong enough to generate a time-relative interest in continuing to live. He is worth quoting at length:

Suppose that a woman who wants to be a single parent becomes impregnated via artificial insemination, but dies during childbirth. She has no close friends and no family - no one to claim the child. The newborn infant is healthy and so is an ideal candidate for adoption. But suppose that, in the same hospital in which the infant is born, there are three other children, all five years old, who will soon die if they do not receive organ transplants. The newly orphaned infant turns out to have exactly the right tissue type: if it were killed, its organs could be used to save the three ailing children. According to the view I have developed, it ought to be permissible, if other things are equal, to sacrifice the newborn orphaned infant in order to save the other three children. [15, p. 359] (cf. $[71$, p. 152])

This frank acknowledgment appears in a discussion of implications of his account that could function as reasons to reject it altogether. Nonetheless, he is willing to bite the bullet because he thinks not biting it leads to morally inconsistent positions, specifically with respect to the treatment of nonhuman animals [73]. By contrast, I have labored to develop an alternative account of the nature of human beings and a morally consistent view of the wrongness of killing to support my judgment. Those who attach moral status to psychological properties that come in degrees should take heed because more is at stake than they might realize. The egalitarian principles, like those found in the Declaration of Independence, that have been foundational to democracy and an impetus for much social progress are at risk of being undermined. 
My view implies that the dignity status we have in virtue of being rational animals is one that does not come in degrees. This all-or-nothing uniformity is precisely what our egalitarian principles require, and they are elegantly satisfied by an all-or-nothing property: the possession of a rational nature. Human dignity is inherent and ineliminable, and there is a duty to respect it at every stage of development and through any degree of (non-ultimate) incapacity in the course of human life. While some may be discomforted by the "conservative" implications this view may have for the practices of abortion, embryonic stem cell research, euthanasia, and physicianassisted suicide, I embrace those implications. One should see my position as resonating with the ethical forecast given by G.B. Giertz at the 1966 Ciba Foundation Symposium on the ethics of transplantation. As he saw it, "respect for the value of the human being and hence for democracy is in danger" when a society embraces social practices that deny "that every human life, even the most wretched, has a meaning” [74, p. 140]—or dignity, as I put it.

Nonetheless, the view that human beings have some sort of non-instrumental worth by virtue of what they are, and that what they are is determined by their ultimate capacities, shares a surprising amount of common ground among philosophers of divergent political persuasions. The so-called "capabilities approach," which recognizes the moral significance of the freedom to pursue one's flourishing and holds that one's opportunity to do so is best understood in terms of one's capabilities (or capacities ${ }^{26}$ ), has been interpreted in various ways through Rawlsian and Aristotelian lenses [76]. Early in her development of the relation between human capabilities and human rights, Nussbaum (a political liberal) notes that one of the senses of capabilities she is working with is that of "basic capabilities"- namely, "the innate equipment of individuals that is

\footnotetext{
${ }^{26}$ I treat these terms as synonymous because both are able to name properties intrinsic to a thing's nature, as they do in Nussbaum's writing in spite of her careful distinction whereby "capabilities" name the morally significant subset of "capacities" distinctive of human nature [74, p. 28].
} 
the necessary basis for developing the more advanced capability" [77, p. 289]. ${ }^{27}$ Similarly, to account for the notion that each of us possesses an ineliminable human dignity, Patrick Lee and Robert George (political conservatives) appeal to the notion of a "basic natural capacity" for conceptual thought that "human beings have in virtue of the kind of entity they are" [79, p. 185]. While I tend to side with Lee and George regarding the ethics of killing, it is striking how prominent the agreement is that a basic capacity (or capability) for rational action is foundational to egalitarian principles. And it is a good thing too. For it provides a principled reason to care for a healthy orphaned newborn infant and soundly reject as impermissible the proposal to kill her for her organs.

\section{Mortal harvesting is incompatible with human equality}

What often goes unnoticed in cases for mortal harvesting is how inimical they are to the notion of human equality. Common to every proposal is the proposition that the organs inside a potential donor are more valuable than the life of the donor. For example, although Miller and Truog believe few would be made dead by mortal harvesting who would not otherwise be made dead by withdrawing life support, they readily acknowledge that some patients will die by transplant surgery who would otherwise continue to live because of an imperfect ability to prognosticate death after the withdrawal of life support [2, p. 116]. They are willing to accept this risk, however, in light of the benefits that would come to organ recipients as well as out of respect for the wishes of the donor to donate. What they are less willing to risk is the possibility

\footnotetext{
${ }^{27}$ Nussbaum has since dropped this conception of basic capability because, in her view, it does not adequately secure the political equality of those with severe mental and cognitive disabilities. She says she thinks "that it is quite crucial not to base the ascription of human dignity on any single 'basic capability' (rationality, for example), since this excludes from human dignity many human beings with severe mental disabilities" [78, p. 362]. As I have tried to show for reasons stated against Singer and McMahan, I do not believe she needed to make this move.
} 
of damaging the organs in a donation-after-circulatory-death protocol. Perhaps for autonomy reasons they would allow such a protocol to be chosen, but it is not to be recommended because it "unnecessarily risks the viability of the organs owing to damage from warm ischemia during the time between cessation of circulation and organ extraction" [2, p. 121]. Consequently, their view implies that the risk of harming the organs outweighs the risk of harming the life of the donor. Of course, the only sense of "harm" they countenance is in terms of setbacks to the donor's interests; intending the destruction of the donor's life falls outside their concept of harm. In this way, they unjustly neglect the non-instrumental worth of human life, which is not possessed by any human organ.

To be sure, the value of the organs in proposals like Miller and Truog's is derived from the value the donor and recipient place on them. Yet this value scheme just reveals that one's life may be medically sacrificed for the sake of another, owing to the assumption that the donor's life is not as worthy of protection from being instrumentalized to the point of death. Mortal harvesting is permissible only if the donor satisfies criteria for what might be called the as-goodas-dead-donor rule (AGDDR). There is no clear consensus on how to determine whether one has satisfied these criteria or could satisfy them, but some suggestions are worth pondering —if only to see how varied and ill-defined they are. Potential donors who are "terminally ill" [80], or have "no hope of meaningful recovery" [81], or are "on a trajectory that with or without organ procurement, would imminently lead to [their] becoming dead by stopping mechanical ventilation" [2, p. 145] are empowered to consent to their deaths via transplant surgery in order to meet the urgent needs of long-suffering recipients, while those who are not in such conditions 
are not. ${ }^{28}$ The latter are permitted to choose mortal harvesting in their living wills in anticipation of when these conditions apply. However, they must make their choice under the policyrecommended premise that life in these conditions is not only not worth living, but also not worth protecting as much as the lives of healthy people. For individuals in these conditions, then, the message is not only that they would be better off dead, but that society would be better off too. ${ }^{29}$ Moreover, as I mentioned above, since people are expected to be rational, those who are in conditions that meet (or are on the cusp of meeting) the AGDDR but who refrain from choosing mortal harvesting must give some reason for doing so on pain of irrationality; this, again, is an intellectual burden no healthy person has to bear and is therefore unfair [22].

The choice to refrain from being mortally harvested is burdened not only intellectually, but also morally. Given that every argument for mortal harvesting cites the dire need for organs, the empowerment to die by transplant surgery quickly moves to an imperative that is easy to justify. One could marshal the framework of Singer's "Famine, Affluence, and Morality" [84] argument to conclude that you act wrongly if you satisfy the AGDDR but forgo organ donation euthanasia. Formulating the argument makes this clear:

1. Suffering and death from the lack of transplantable organs is bad.

2. If it is in your power to prevent something bad from happening, without giving up anything of equal importance, it is wrong for you not to do so.

3. If you (could) satisfy the AGDDR (e.g., you are terminally ill, have no hope of meaningful recovery, or are on a fatal trajectory), then it is in your power to prevent suffering and death by donating as many transplantable organs as you can, without sacrificing anything nearly as important.

4. Therefore, if you (could) satisfy the AGDDR and you refrain from donating, you are

\footnotetext{
${ }^{28}$ Perhaps one of the stranger conditions suggested in the literature is the condition of being engaged in "the Heideggerean activity of 'Being-towards death"” [82, p. 448].

${ }^{29}$ For an interesting analysis of the "expressivist objection," see Philip Reed [83].
} 
wrong to do so.

All parties to the debate agree with the first premise. Nearly everyone agrees with the second, as it seems perfectly wasteful to forbid transplants from freshly dead bodies. Yet the third is precisely what is at issue: Mortal harvesting could not be justified as a matter of public policy without affirming it, and eligible donors would then be saddled with its moral stigma despite being permitted to refrain from sacrificing their lives. Now, an eligible donor could invoke what I have argued for here to say that there is something that would be sacrificed that is just as important as preventing suffering and death for another person — that is, the inherent dignity of the individual human person in her embodied life and the pursuit of that life. While I believe this is a good reason for an eligible donor to refrain from undergoing mortal harvesting, the point is that no patient should have to bear the weight of rebutting this (question-begging) argument, which simply assumes, as a matter of policy, that the inherent dignity of the human person is not a decisive reason for continuing to live.

Worse yet, policy makers who would establish mortal-harvesting practices seem indifferent to the fact that a certain set of (perhaps unreliable) quality-of-life judgments, along with their lethal implications, would become a systematic part of the transplant enterprise. No doubt, these judgments are probably already tacitly involved in the system, but it does not follow that codifying them into formal policy would somehow be an improvement over the status quo. It is doubtful that criteria for determining whether one satisfies the AGDDR would be better defined than the current diagnostic criteria for death, and in time the categories are likely to expand to include those who claim "unbearable suffering" - a trajectory noticeable in parts of Europe [85]. Furthermore, if these proposals were to be adopted, then there would be no reason why one should not be able to lethally experiment on the same class of people, so long as they consent to 
being used lethally for the sake of gaining medical knowledge. ${ }^{30}$ This allowance would, of course, undercut the fundamental ethical principles long recognized by the Nuremberg Code, the Declaration of Helsinki, and the Belmont Report [29; 86, pp. 181-182; 87]. To allow mortal harvesting is not just to rethink the ethics of death, dying, and organ transplantation, but to destabilize the whole bioethical enterprise itself. Are advocates of mortal harvesting prepared to go as far as their principles will take them? If not, why not?

\section{Conclusion}

In this paper, I have labored to identify the basis that grounds our protections against killing with something that does not come in degrees_-namely, our kind-specific rational nature. Along the way, I have advocated for a model in which our dignity is bound up with a way of being rather than a way of becoming. If you bear a life form with a rational nature, you have dignity; every human being bears such a life form, so every one of us has dignity status. Concomitant to this belief is that our dignity is ineliminable, which makes it the case that our suffering always matters. Related to this view is a belief that I have not argued for here: we are not merely receptacles of value whose claim to life wholly depends on whether we can be the subject of some good state of affairs or pleasurable sensation. Modern accounts of killing tend to reduce human worth to the degree of happy properties one contingently exemplifies (which are just matters of fortune) and leave our natural, intrinsic dignity behind. Such accounts are, as Chappell says, "metaphysically superficial, because these accounts focus on what's secondary, the

\footnotetext{
${ }^{30}$ It may be argued that the goods of medical knowledge are further off in the future and not as immediately tangible as those of organ donation. That probably is the case for most scientific experiments, but it is not hard to imagine some emergency involving an experimental intervention that could save a life except if only the physician could learn some more about it before using it, given that it has a severe risk of causing death. The rules against lethal experimentation of this sort are based on the same principles that are foundational to the dead-donor rule.
} 
properties of the individual person, while ignoring or bypassing the primary thing, the person herself" [37, p. 108]. Perhaps this focus on properties over persons is a consequence of the culture's move toward secularization, which leaves behind the idea that human beings are made in the image God. Geirtz certainly had this in mind when he remarked at the Ciba meeting that "the concept of unconditional human worth cannot, however, be justified rationally" [74, p. 140] - the implication being that it can only be accepted as a matter of blind faith. My hope is that I have demonstrated that the unconditionality of human worth can indeed be accepted rationally as well. Once it is accepted as such, it becomes clear that killing people for their organs is disrespectful to the lives of the donors because ultimately this practice means that a higher value has been placed on the organs themselves than on the ones who carry them.

Acknowledgments The author is grateful for the helpful feedback provided by Christopher Tollefsen, Jason Eberl, and Christopher Grau on previous drafts of this paper. A special thanks goes to the copyeditor of this journal, Katie McDougald, whose countless edits made for a much more felicitous reading of the final manuscript. 


\section{References}

1. Wilkinson, Dominic, and Julian Savulescu. 2012. Should we allow organ donation euthanasia? Alternatives for maximizing the number and quality of organs for transplantation. Bioethics 26: 32-48.

2. Miller, Franklin G., and Robert D. Truog. 2012. Death, dying, and organ transplantation: Reconstructing medical ethics at the end of life. Oxford: Oxford University Press.

3. Bollen, Jan, David Shaw, Guido de Wert, Rankie ten Hoopen, Dirk Ysebaert, Ernst van Heurn, and Walther van Mook. 2020. Organ donation euthanasia (ODE): Performing euthanasia through living organ donation. Transplantation 104: S298.

4. Khushf, George. 2010. A matter of respect: A defense of the dead donor rule and of a "whole-brain" criterion for determination of death. Journal of Medicine and Philosophy 35: 330-364.

5. Gaylin Willard, Leon R. Kass, Edmund D. Pellegrino, and Mark Siegler. 1988. Doctors must not kill. JAMA 259: 2139-2140.

6. Dalle Ave, Anne L., Daniel P. Sulmasy, and James L. Bernat. 2020. The ethical obligation of the dead donor rule. Medicine, Health Care, and Philosophy 23: 43-50.

7. Omelianchuk, Adam. 2018. How (not) to think of the 'dead-donor' rule. Theoretical Medicine and Bioethics 39: 1-25.

8. Anscombe, G.E.M. 2005. Prolegomenon to a pursuit of the definition of murder: The illegal and the unlawful. In Human life, action and ethics: Essays by G.E.M. Anscombe, ed. Mary Geach and Luke Gormally, 253-260. Exeter: Imprint Academic.

9. Anscombe, G.E.M. 2005. Murder and the morality of euthanasia. In Human life, action and ethics: Essays by G.E.M. Anscombe, ed. Mary Geach and Luke Gormally, 261-278. Exeter: Imprint Academic.

10. Marquis, Don. 1989. Why abortion is immoral. Journal of Philosophy 86: 183-202.

11. Glover, Jonathan. 1977. Causing death and saving lives. Harmondsworth: Penguin.

12. Quinn, Warren. 1984. Abortion: Identity and loss. Philosophy and Public Affairs 13: 24-54.

13. Harris, John. 1992. Wonderwoman and superman: The ethics of human biotechnology. Oxford: Oxford University Press.

14. Harris, John. 1975. The survival lottery. Philosophy 50: 81-87.

15. McMahan, Jeff. 2002. The ethics of killing: Problems at the margins of life. New York: Oxford University Press.

16. Luper, Steven. 2009. The philosophy of death. Cambridge: Cambridge University Press.

17. Feinberg, Joel. 1984. Harm to others. Oxford: Oxford University Press.

18. Elliott, Carl. 1995. Doing harm: Living organ donors, clinical research and The Tenth Man. Journal of Medical Ethics 21: 91-96. 
19. Rachels, James. 1986. The end of life: Euthanasia and morality. Oxford: Oxford University Press.

20. Sinnott-Armstrong, Walter, and Franklin G. Miller. 2013. What makes killing wrong? Journal of Medical Ethics 39: 3-7.

21. Menikoff, Jerry. 2003. Why being alive matters. American Journal of Bioethics 3(1): 21-22.

22. Velleman, J. David. 1992. Against the right to die. Journal of Medicine and Philosophy 17: $665-681$.

23. Oderberg, David S. 2000. Applied ethics: A non-consequentialist approach. Oxford: Blackwell.

24. Doyal, Len. 2006. Dignity in dying should include the legalization of non-voluntary euthanasia. Clinical Ethics 1: 65-67.

25. Callahan, Daniel. 1993. The troubled dream of life: In search of a peaceful death. New York: Simon and Schuster.

26. Savulescu, Julian. 2018. The structure of ethics review: Expert ethics committees and the challenge of voluntary research euthanasia. Journal of Medical Ethics 44: 491-493.

27. Boethius. 1918. The theological tractates; and the consolation of philosophy. Trans. and ed. H.F. Stewart and E.K. Rand. London: Heinemann.

28. Simpson, Peter. 1988. The definition of person: Boethius revisited. The New Scholasticism 62: 210-220.

29. National Commission for the Protection of Human Subjects of Biomedical and Behavioral Research. 1979. The Belmont report: Ethical principles and guidelines for the protection of human subjects of research. Washington, DC: US Government Printing Office.

30. Lysaught, M. Therese. 2004. Respect: Or, how respect for persons became respect for autonomy. Journal of Medicine and Philosophy 29: 665-680.

31. Beauchamp, Tom L., and James F. Childress. 1979. Principles of biomedical ethics, 1 st ed. New York: Oxford University Press.

32. National Institutes of Health. 1994. Report of the human embryo research panel, vol. 1. Bethesda, MD: National Institutes of Health.

33. Ramsey, Paul. 1970. The patient as person: Explorations in medical ethics. New Haven: Yale University Press.

34. Ramsey, Paul. 1968. The morality of abortion. In Life or death: Ethics and options, ed. Edward Shils, 60-93. Portland, OR: Reed College.

35. Ethics Advisory Board, Department of Health, Education, and Welfare. 1979. Report and conclusions: HEW support of research involving human in vitro fertilization and embryo transfer. Washington, DC: US Government Printing Office.

36. Paterson, Craig. 2008. Assisted suicide and euthanasia: A natural law ethics approach. London: Routledge.

37. Chappell, Timothy. 2004. Absolutes and particulars. In Modern moral philosophy, ed. Anthony O’Hear, 95-115. Cambridge: Cambridge University Press. 
38. Kant, Immanuel. 1990. Foundations of the metaphysics of morals, 2nd ed, trans. Lewis White Beck. New York: Macmillan.

39. Wasserman, David, Adrienne Asch, Jeffrey Blustein, and Daniel Putnam. 2017. Cognitive disability and moral status. In The Stanford encyclopedia of philosophy, Fall 2017 ed, ed. Edward N. Zalta. Stanford: Metaphysics Research Lab. https://plato.stanford.edu/archives/fall2017/entries/cognitive-disability.

40. Vukov, Joseph. 2017. Personhood and natural kinds: Why cognitive status need not affect moral status. Journal of Medicine and Philosophy 42: 261-277.

41. Thompson, Michael. 2004. Apprehending human form. In Modern moral philosophy, ed. Anthony O’Hear, 47-74. Cambridge: Cambridge University Press.

42. Foot, Philippa. 2001. Natural goodness. Oxford: Oxford University Press.

43. Thompson, Michael. 2008. Life and action: Elementary structures of practice and practical thought. Cambridge: Harvard University Press.

44. Frey, Jennifer A. 2019. Neo-Aristotelian ethical naturalism. In The Cambridge companion to natural law ethics, ed. Tom Angier, 92-109. Cambridge: Cambridge University Press.

45. Moravcsik, Julius. 1994. Essences, powers, and generic propositions. In Unity, identity, and explanation in Aristotle's metaphysics, ed. T. Scaltsas, D. Charles, and M.L. Gill, 229-244. Oxford: Oxford University Press.

46. MacIntyre, Alasdair C. 1999. Dependent rational animals: Why human beings need the virtues. Chicago: Open Court.

47. Matchulat, Justin. 2015. Rationality and human value: An Aristotelian response to Robert Adams. Faith and Philosophy 32: 404-422.

48. DiSilvestro, Russell. 2010. Human capacities and moral status. Dordrecht: Springer.

49. Schiff, Nicholas D., and Joseph J. Fins. 2007. Hope for "comatose" patients. In Cerebrum 2007: Emerging ideas in brain science, ed. Cynthia A. Read, 185-203. Washington, DC: Dana Press.

50. Moreland, J.P., and Scott B. Rae. 2000. Body and soul: Human nature and the crisis in ethics. Downers Grove, IL: InterVarsity Press.

51. Marquis, Donald. 2011. Why abortion is seriously wrong: Two views. In Bioethics with liberty and justice, ed. Christopher Tollefsen, 3-22. Dordrecht: Springer.

52. Singer, Peter. 1994. Rethinking life and death: The collapse of our traditional ethics, 2nd ed. New York: St. Martin's Griffin.

53. McMahan, Jeff. 2008. Challenges to human equality. Journal of Ethics 12: 81-104.

54. Goodwin, Brian C. 1994. How the leopard changed its spots: The evolution of complexity. Princeton: Princeton University Press.

55. Baker, Stuart G. 2015. A cancer theory kerfuffle can lead to new lines of research. Journal of the National Cancer Institute 107(2): 1-8. https://doi.org/10.1093/jnci/dju405.

56. Prehn, Richmond T. 1994. Cancers beget mutations versus mutations beget cancers. Cancer Research 54: 5296-5300. 
57. Mulgan, Tim. 2004. Critical notice of The Ethics of Killing: Problems at the Margins of Life, by Jeff McMahan. Canadian Journal of Philosophy 34: 443-459.

58. Grau, Christopher. 2015. McMahan on speciesism and deprivation. Southern Journal of Philosophy 53: 216-226.

59. Aristotle. 1941. Metaphysica, trans. W.D. Ross. In The basics works of Aristotle, ed. Richard McKeon, 689-926. New York: Modern Library.

60. Nussbaum, Martha C. 2006. Frontiers of justice: Disability, nationality, species membership. Cambridge: Harvard University Press.

61. Omelianchuk, Adam. 2021. Brain death as the end of a human organism as a self-moving whole. Journal of Medicine and Philosophy 46: 530-560.62. Olson, Eric T. 2009. An argument for animalism. In Defining the beginning and end of life: Readings on personal identity and bioethics, ed. John P. Lizza, 80-98. Baltimore: Johns Hopkins University Press.

63. Lee, Patrick, and Robert P. George. 2008. Body-self dualism in contemporary ethics and politics. New York: Cambridge University Press.

64. Gray, Sarah. 2016. A life everlasting: The extraordinary story of one boy's gift to medical science. New York: HarperOne.

65. Tollefsen, Christopher. 2010. Disability and social justice. In Philosophical reflections on disability, ed. D. Christopher Ralston and Justin Hubert Ho, 211-227. Dordrecht: Springer.

66. Eberl, Jason T. 2011. The unactualized potential of PVS patients. APA Newsletter 11: 1418.

67. Lizza, John P. 2011. On the ethical relevance of active versus passive potentiality. APA Newsletter 11: 22-28.

68. Koppelman, Elysa R. 2003. The dead donor rule and the concept of death: Severing the ties that bind them. American Journal of Bioethics 3(1): 1-9.

69. Zohar, Noam J. 2003. The end of humanity: Does circumventing "death" help the cause? American Journal of Bioethics 3(1): 12-13.

70. Cholbi, Michael. 2000. Kant and the irrationality of suicide. History of Philosophy Quarterly 17: 159-176.

71. Kant, Immanuel. 1964. The metaphysical principles of virtue, trans. James Ellington. Indianapolis: Bobbs-Merrill.

72. McMahan, Jeff. 2007. Infanticide. Utilitas 19: 131-159.

73. McMahan, Jeff. 2013. Infanticide and moral consistency. Journal of Medical Ethics 39: 273-280.

74. Giertz, G.B. 1966. Ethical problems in medical procedures in Sweden. In Ethics in medical progress: With special reference to transplantation, ed. G.E.W. Wolstenholme and Maeve O’Connor, 139-148. Boston: Little, Brown.

75. Nussbaum, Martha C. 2011. Creating capabilities: The human development approach. Cambridge: Harvard University Press. 
76. Robeyns, Ingrid. 2016. The capability approach. In The Stanford encyclopedia of philosophy, Winter 2016 ed, ed. Edward N. Zalta. Stanford: Metaphysics Research Lab. https://plato.stanford.edu/archives/win2016/entries/capability-approach.

77. Nussbaum, Martha C. 1997. Capabilities and human rights. Fordham Law Review 66: 273300 .

78. Nussbaum, Martha. 2008. Human dignity and political entitlements. In Human dignity and bioethics: Essays commissioned by the President's Council on Bioethics, ed. President's Council on Bioethics, 351-380. Washington, DC: President's Council on Bioethics.

79. Lee, Patrick, and Robert P. George. 2008. The nature and basis of human dignity. Ratio Juris 21: 173-193.

80. Verheijde, Joseph L., Mohamed Y. Rady, and Joan McGregor. 2007. Recovery of transplantable organs after cardiac or circulatory death: Transforming the paradigm for the ethics of organ donation. Philosophy, Ethics, and Humanities in Medicine 2: 8. https://doi.org/10.1186/1747-5341-2-8.

81. Glannon, Walter. 2013. The moral insignificance of death in organ donation. Cambridge Quarterly of Healthcare Ethics 22: 192-202.

82. Isch, D.J. 2007. In defense of the reverence of all life: Heideggerean dissolution of the ethical challenges of organ donation after circulatory determination of death. Medicine, Health Care and Philosophy 4: 441-459.

83. Reed, Philip. 2020. Expressivism at the beginning and end of life. Journal of Medical Ethics 46: 538-544.

84. Singer, Peter. 1972. Famine, affluence, and morality. Philosophy and Public Affairs 1: 229243.

85. Ely, E. Wesley. 2019. Death by organ donation: Euthanizing patients for their organs gains frightening traction. Intensive Care Medicine 45: 1309-1311.

86. Allied Control Council. 1949. Trial of war criminals before the Nuernberg military tribunals under Control Council Law No. 10, vol. 2: The medical case. Washington, DC: US Government Printing Office. https://www.loc.gov/rr/frd/Military_Law/NTs_warcriminals.html.

87. World Medical Association. 2013. World Medical Association Declaration of Helsinki: Ethical principles for medical research involving human subjects. JAMA 310: 2191-2194. 